\title{
THE PRELIMINARY DESIGN AND TECHNICAL-ECONOMIC EFFICIENCY OF THE TWO-LEVEL BRANCHED CABLE-STAYED BRIDGE
}

\author{
Modestas STRAGYS* \\ Vilnius Gediminas Technical University, Sauletekio al. 11, LT-10223, Vilnius, Lithuania
}

Received 28 September 2018; accepted 19 December 2018

\begin{abstract}
An innovative steel cable-stayed pedestrian bridge structure and the preliminary design methodology are provided in this article. The advantages and disadvantages of the bridge design are presented. The comparative analysis of the innovative steel cable-stayed pedestrian bridge structure and a similar structure of a single pylon fan cable-stayed bridge with an $80 \mathrm{~m}$ span is provided, the main criteria are reviewed and conclusions are formulated. The main features of the innovative branched cable-stayed bridge behaviour are reviewed. An overview of technical-economic efficiency and conclusions are presented.
\end{abstract}

Keywords: cable-stayed bridge, nonlinear analysis, stress and strain state, technical-economic efficiency, innovative structure, preliminary design.

\section{Introduction}

Cable-stayed bridges have been widely used since the 1950s. Due to their unique, cost-effective, lightweight and easy-to-install structure these bridges have become a very popular solution for medium and long spans (Podolny, 2011). Cable-stayed bridges are among the most promising modern bridge systems. Their lightweight, durable and aesthetic expression is one of the main reasons for its popularity. However, despite all the advantages which are crucial for bridge building, cable-stayed bridges have several features that place significant constraints on the design of such systems. Some of the main and constant challenges for the engineers are deformability and the non-linear behaviour of such a system. The current design calculations are based on provisions that allow "to bypass" the deformed state analysis. However, it is not sufficiently clear as of now what the errors of such simplified calculation are. An equivalent modulus of elasticity is introduced in the cable calculations which allows one to model the inclined cable as a fictitious straight bar. It is not clear what the real impact of such simplification on the calculation results is. Engineers lack the knowledge which could be used in the practical tasks, therefore, data on the behaviour of such bridges and preliminary calculations of such structures are necessary.

The continuing trend is always towards creating more lightweight and stable cable-stayed bridge structures that could be used for larger spans. Engineers face many challenges in achieving this goal.

A lot of research have been published on the deformed state of the cable-stayed bridges. The nonlinear cablestayed bridge behaviour is described in detail by Nazmy and Abdel-Ghaffar (1990) in "Three-dimensional nonlinear static analysis of cable-stayed bridges". It describes the three main reasons for geometrical non-linearity and presents their corresponding calculations.

Despite the fact that the cable-stayed bridge structure element materials work according to material linear model, the displacement ratio of the structure load itself is geometrically non-linear under the design loads. Such geometrically non-linear behaviour is present for three main reasons (Nazmy \& Abdel-Ghaffar, 1990):

- Nonlinear axial force-elongation relationship for the inclined cable stays due to the sag caused by their own weight;

- Nonlinear axial force and bending moment relationship for the pylons and longitudinal stiffening girder elements;

- Change of the bridge geometry due to large displacements.

Another research with large coverage on geometrically non-linear analysis and deformed state is "Second-order inelastic analysis of cable-stayed bridges" by Thai and Kim

*Corresponding author. E-mail: modestas.stragys@vgtu.lt 
(2012). It also provides reasons for geometrical non-linearity and possible calculations of such behaviour. A considerable amount of articles is written on cable behaviour and its simplified calculations. This includes the following research: Wang, Lin, and Tang (2002) "Study on nonlinear analysis of a highly redundant cable-stayed bridge", as well as Hajdin, Michaltsos, and Konstantakopoulos (1998) "About the equivalent modulus of elasticity of cables of cable-stayed bridges" and Freire, Negrao, and Lopes (2006) "Geometrical nonlinearities on the static analysis of highly flexible steel cable-stayed bridges". Some of the research also goes to the core of the nonlinear behaviour of bending elements which is especially important for the stiffening girder of the cable-stayed bridges.

Since the analysis of the deformed state is rather complicated, various simplified calculations are being developed. One of the first to develop and describe such calculations in the field of cables was Dischinger (1949) in "Hängebrücken fur Schwerste Verkehrslasten" and Ernst (1965) in "Der E-Modul von Seilen unter Brucksichtigung des Durchhangers". They refer to the equivalent modulus of elasticity which assists in approximate estimations of the cable sag. Later more research was made on this subject-matter, such as "The tangent and secant modulus of cable stays with tension cables" by Monaco (1997).

"Structural analysis: a unified classical and matrix approach" by Ghali and Neville (1978) speaks of the bending elements and their calculations. These provide examples of various structures that can also be applied in the cablestayed bridge calculations. A more detailed analysis of this issue is provided by Vega-Posada, Areiza-Hurtado, and Aristizabal-Ochoa (2011) in "Large-deflection and postbuckling behavior of slender beam-columns with nonlinear end-restraints".

As for preliminary design one article by Hagen and Staroseek (2002) "Zur Vorbemessung von Schrägseilbrücken" is particularly significant. It contains the preliminary calculations of stress and strain as well as methods for preliminary identification of the stay cable stress.

This article examines the new innovative two-level branched cable-stayed bridge behaviour. The preliminary design methodology for this type of bridges is presented. The advantages of such structure are indicated and a comparative analysis of the standard fan cable-stayed bridge of a similar length is performed.

\section{New structural form}

New innovative systems are constantly being developed in an effort to minimize the possible construction costs by ensuring the same design structure parameters. One of these systems is the branched cable-stayed bridges (Figure 1). Such solution for bridges could be driven by the need to significantly reduce the cost of materials for the construction of cable-stayed bridges and, at the same time, to effectively manage the stress on the bridge elements.

\section{Preliminary design}

\section{Cable connection coordinates and displacements}

It is common that in order to achieve rational bending moments in the cable-stayed bridge stiffening girder, it is necessary to provide the cables with a certain prestress force and to select the required cross-sectional area. In the case of the branched bridge another important indicator is in place which is the cable length, or, in other words, the coordinate of the cable intersection point.

The reaction of the system is particularly sensitive to the displacements of these connections, and the distribution of stresses depends much more on the this than on the cable cross-section area or prestress force, as is the usual case with the standard cable-stayed bridges. The latter are only tools to ensure efficient cable performance. The connection coordinates are extremely significant for one reason: the balance of forces. In each of the connections the balance between the vertical and the horizontal forces must be achieved, otherwise, the performance of the cables will be inefficient, the prestress force will go up resulting in an increase in the cross-sectional area of the cable and the steel costs will grow without any serious cause. Moreover, in case of a certain load applied to the stiffening girder the connection displacements will no longer meet the serviceability limit state requirements, the system will be unstable and the stresses will be difficult to control. The difference in bridge behaviour with adjusted and non-adjusted cable coordinates is shown in Figures 2a and $2 \mathrm{~b}$, respectively.

The difference shown is obvious. In the first case the cables are displaced downward at more than $10 \mathrm{~cm}$. Such displacements are unacceptable and even dangerous to the structure. In the second case the balance of forces in the connections is achieved and minimal displacements occur only due to the deflection of the stiffening girder and cable elasticity.

\section{Engineering calculation methodology}

Based on the statement that one of the most important design aspects of the two-level branched cable-stayed bridges is the coordinates of cable connections, recommendations for the calculation of the cable connection coordinates for the cable-stayed bridges where cables are branched up to 2 times were prepared. Such branches are called levels. The first level in this case is the upper connection, the second level connections are the lower ones (Figure 3).

The identification of the cable connection coordinates of two-level (or one-level) cable-stayed bridge is carried out according to the algorithm shown in Figure 4.

\section{Determination of the pylon coordinates}

$$
H=0,577 \cdot L,
$$

where: $H$ - pylon height from the axis of the stiffening girder; $L$ - the length of the stiffening girder from its edge to the pylon. 


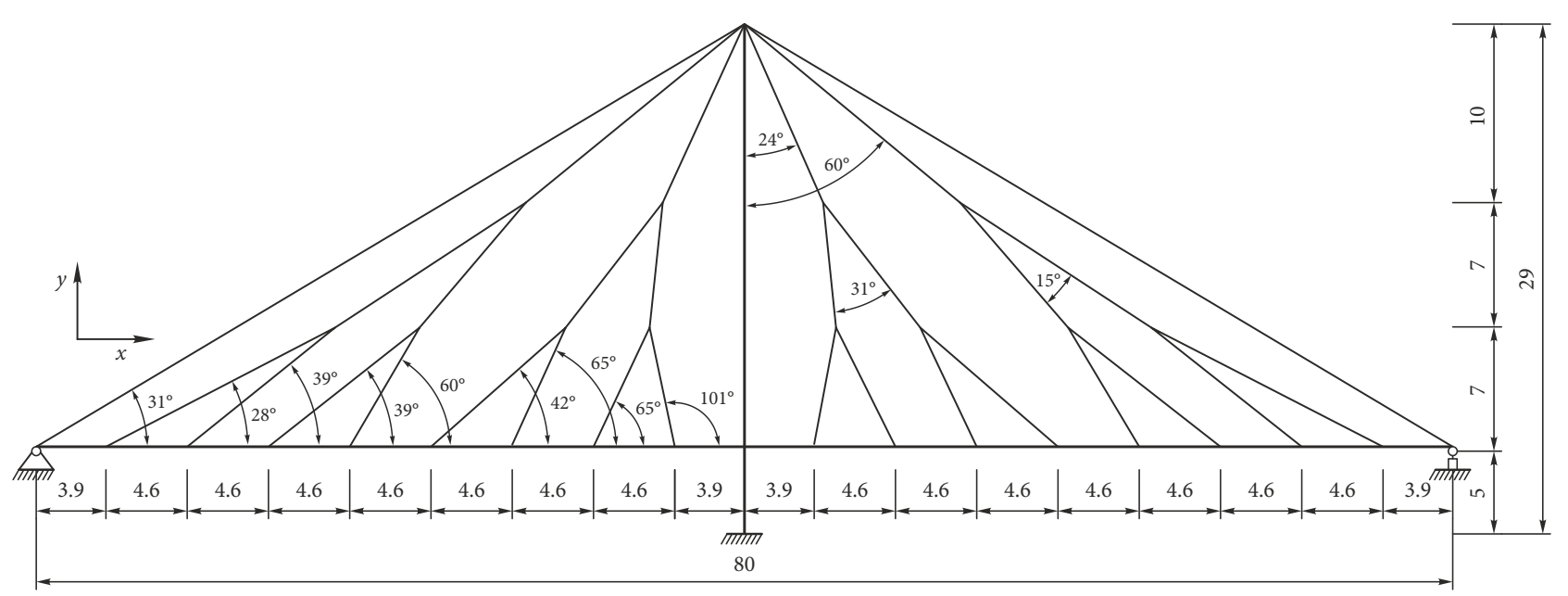

Figure 1. The scheme of the branched cable-stayed bridge
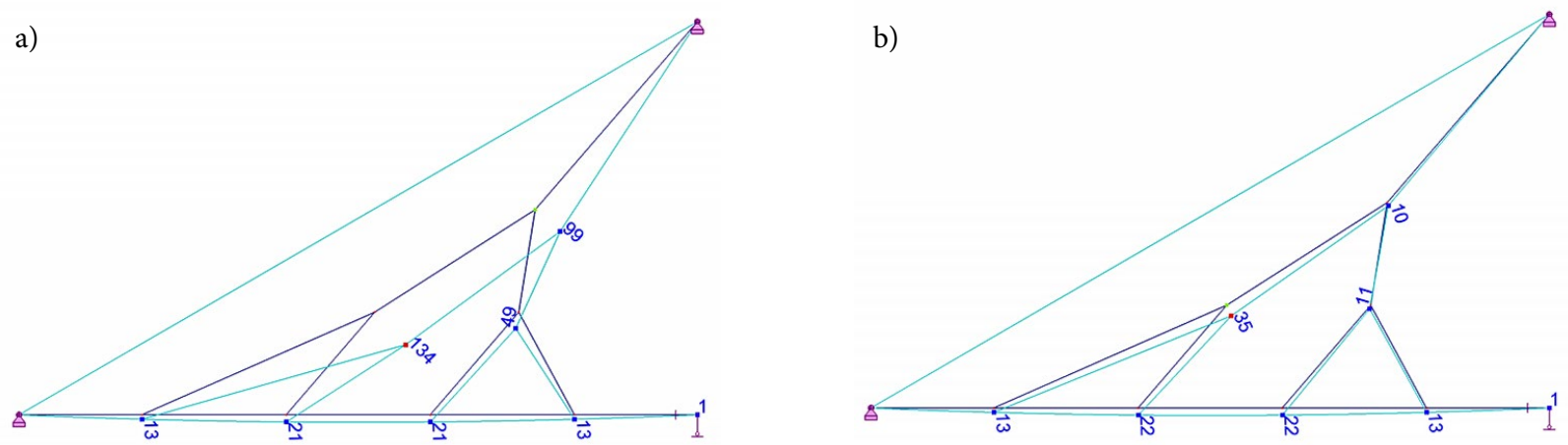

Figure 2. a) - system displacements without the balance of axial forces in the cable connections; b) - system displacements with the balance of axial forces in the cable connections

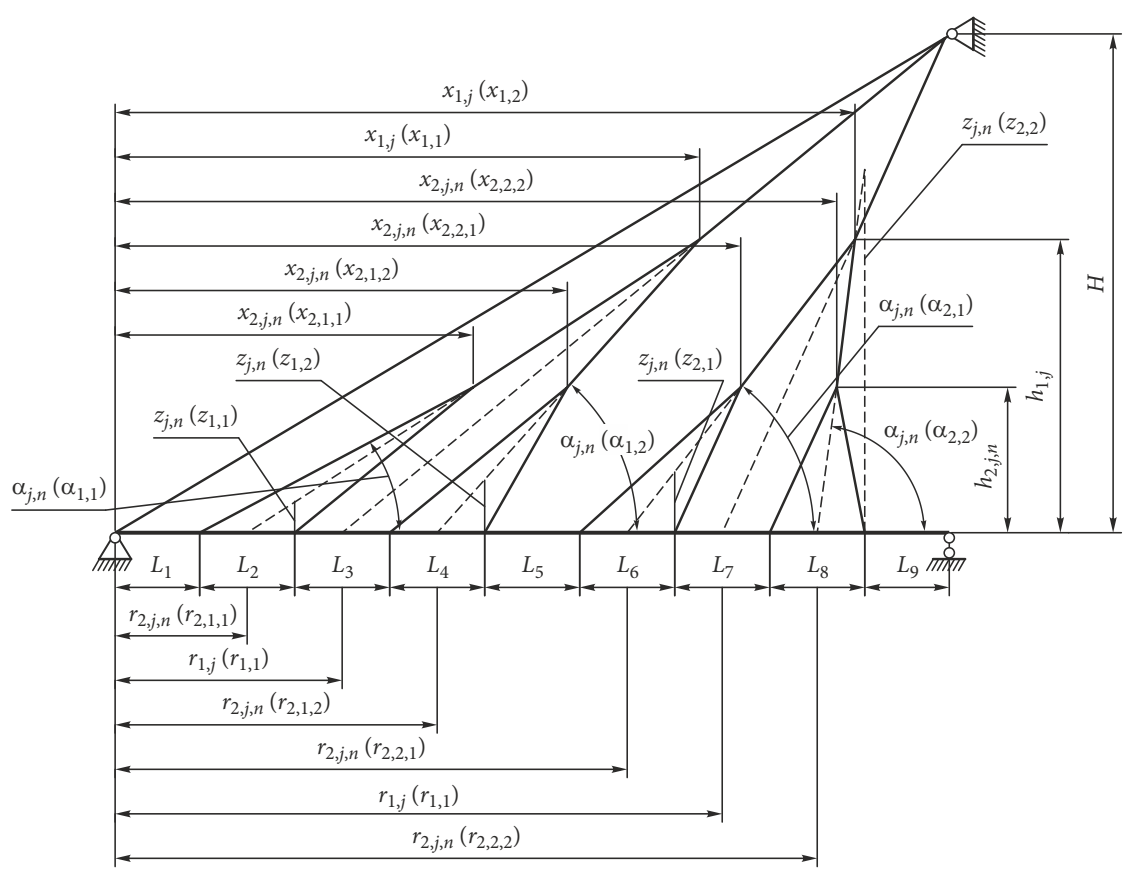

Figure 3. Cable connection coordinate calculation scheme 


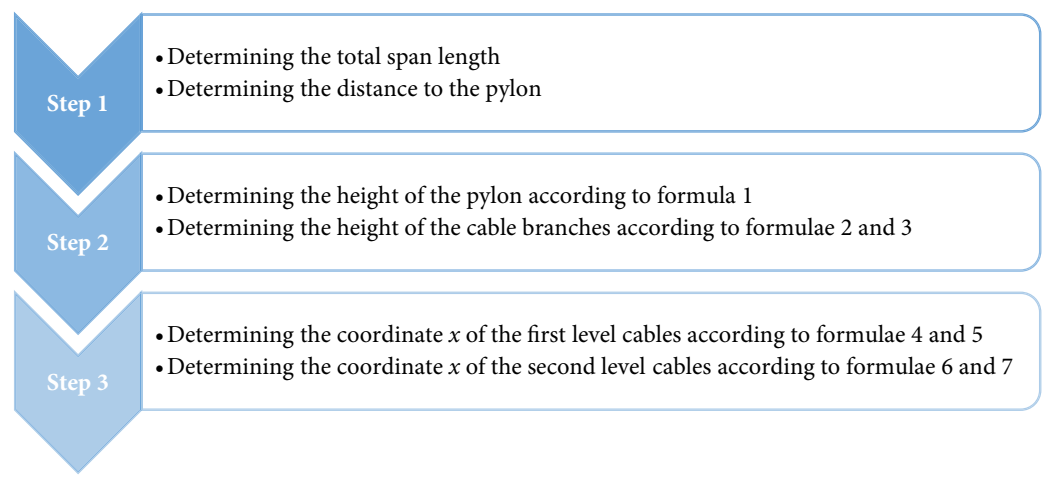

Figure 4. Algorithm for finding the coordinates of the cable connections of the branched cable-stayed bridge

$$
\begin{aligned}
& h_{1, j}=\frac{7}{12} \cdot H ; \\
& h_{2, j, n}=\frac{1}{4} \cdot H,
\end{aligned}
$$

where: $h_{1, j}$ - the height of the first level cable branch $j$ from the stiffening girder axis; $h_{2, j, n}$ - height from the stiffening girder to the second level branch; $H$ - pylon height from the stiffening girder axis.

\section{Determination of the first level coordinates $x$}

$$
x_{1, j}=r_{1, j}+\frac{r_{1, j} \cdot h_{1, j}}{H},
$$

where $x_{1, j}$ - the distance of the first level cable branch $j$ from the stiffening girder edge; $h_{1, j}$ - the distance of the first level cable branch $j$ from the stiffening girder axis; $H$ - pylon height from the stiffening girder axis; $r_{1, j}$ - fictitious intersection point of the first level $j$-cable with the stiffening girder calculated according to formula 4 :

$$
r_{1, j}=\sum_{i=1}^{4 j-3} L_{i}+\frac{3 \cdot L_{4 j-2}}{4}+\frac{L_{4 j-1}}{2}+\frac{L_{4 j}}{4},
$$

where: $L_{i}$ - the length of the $i$ stiffening girder distance between the cables.

\section{Determination of the second level coordinates}

$$
x_{2, j, n}=r_{2, j, n}+\frac{\left(x_{1, j}-r_{2, j, n}\right) \cdot h_{2, j, n}}{h_{1, j}},
$$

where: $x_{2, j, n}$ - the distance of the second level branch from the stiffening girder edge; $x_{1, j}$ - the distance of the first level branch from the stiffening girder edge; $h_{2, j, n}$ - height from the stiffening girder to the second level branch; $h_{1, j}-$ height from the stiffening girder to the first level branch; $r_{2, j, n}$ - fictitious intersection point of the first level $n$-cable with the stiffening girder calculated according to:

$$
r_{2, j, n}=\sum_{i=1}^{2 n-1} L_{i}+\frac{L_{2 n}}{2},
$$

where: $L_{i}$ - the length of the i stiffening girder distance between the cables; $L_{2 n}$ - the length of the $2 n$ stiffening girder distance between the cables.

\section{Bridge behaviour comparative analysis}

For the purpose of identifying the behaviour of the new structure behaviour the following loads are assessed: the dead load of the structures and the temporary pedestrian loads. With the use of these loads the structure is tested according to two combinations: the symmetric (when the pedestrian load is applied across the entire bridge) and asymmetric (when the pedestrian load is applied to only one side of the bridge). The variable load of the pedestrian bridge is the pedestrian traffic load. It is calculated in accordance with LST EN 1991-2; 2006 - 5.1.(2) (Lietuvos Standartizacijos departamentas, 2006). The 4th load model is applied - the crowd load - which is equal to $q_{k, f}=5 \frac{\mathrm{kN}}{\mathrm{m}^{2}}$. This load is distributed to longitudinal girders, symmetric and asymmetric load variations are developed.

The stiffening girder of the bridge under analysis (Figure 5) is $80 \mathrm{~m}$ in length, designed from the IPE 450 profile. The pylon is designed from a square cross-section element with a length and width of $550 \mathrm{~mm}$ and the wall thickness of $30 \mathrm{~mm}$. The anchor cables are modelled from $110 \mathrm{~mm}$ diameter cables. The first level cables starting from the anchor cable are $90 \mathrm{~mm}$ and $60 \mathrm{~mm}$ in diameter. The second level cables starting from the anchor cable are $70 \mathrm{~mm}, 70 \mathrm{~mm}, 50 \mathrm{~mm}$ and $50 \mathrm{~mm}$ in diameter. The third level cables starting from the anchor cable are $70 \mathrm{~mm}, 60 \mathrm{~mm}, 70 \mathrm{~mm}, 60 \mathrm{~mm}, 40 \mathrm{~mm}, 30 \mathrm{~mm}, 40 \mathrm{~mm}$ and $30 \mathrm{~mm}$ in diameter.

The innovative bridge is compared to the conventional cable-stayed bridge (Figure 6). The stiffening girder of this bridge is respectively $80 \mathrm{~m}$ long, designed from the IPE 500 profile. The pylon is designed from a square cross-section element with a length and width of $500 \mathrm{~mm}$ and the wall thickness of $20 \mathrm{~mm}$. The anchor cables are modelled from $80 \mathrm{~mm}$ diameter cables. The other three cables, arranged in a row starting from the anchor cable, are $50 \mathrm{~mm}$ in diameter, while the three cables closest to the pylon are $40 \mathrm{~mm}$ in diameter.

The cable cross-section area and prestress force is selected in such a way as to maximize the rationality of the stresses in the stiffening girder. The adjustment of the stresses can only be done by increasing the cable diameter. 
In this way the cable becomes more rigid and its deformation decreases, the support for the stiffening girder is greater. The problem with this method is that the cables are expensive, thus, the option of increasing the diameter is extremely non-cost-effective. Also, the stresses can be adjusted by applying the prestress force only, however, in this case an extremely high prestress force is required and the cable may break. In this case both methods were combined. The cable diameter was selected according to the strength conditions, and only then the prestress force was provided. This way the most efficient and cost-effective option is achieved. The stress control in the case of an innovative bridge is even more complicated, as the third element is added: the cable connection coordinates, the calculation of which is presented in the second section.

\section{The analysis of bending moments}

Under the symmetric load the bending moments in the stiffening girder are evenly distributed due to the imposed loads (Figure 7). The highest value in stiffening girder reaches only $72.99 \mathrm{kNm}$, while the lowest is $63.36 \mathrm{kNm}$. The 13\% difference between the maximum and minimum bending moments in the stiffening girder is formed due to the rather complicated cable system.

Under the asymmetric load the bending moments in the stiffening girder are different in their values on the right and the left sides due to the imposed loads (Figure 8). Since the pedestrian load is only on the left side this is exactly where the moments increase, while they decrease on the right side. The uneven bending moments can be seen on the left side. The bending moments are rising upwards

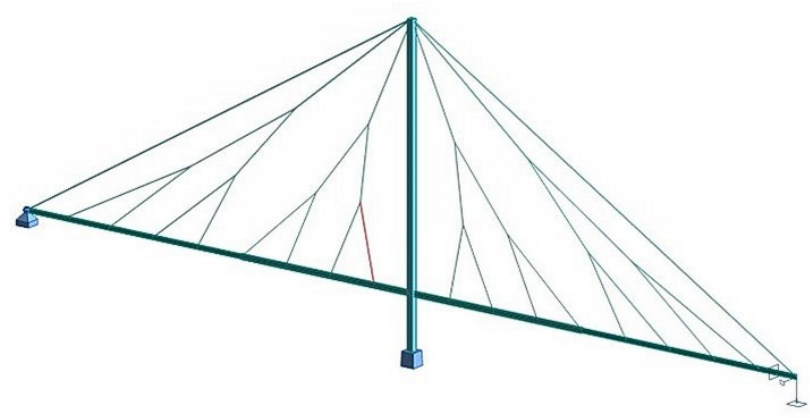

Figure 5. The new innovative branched cable-stayed bridge structure scheme

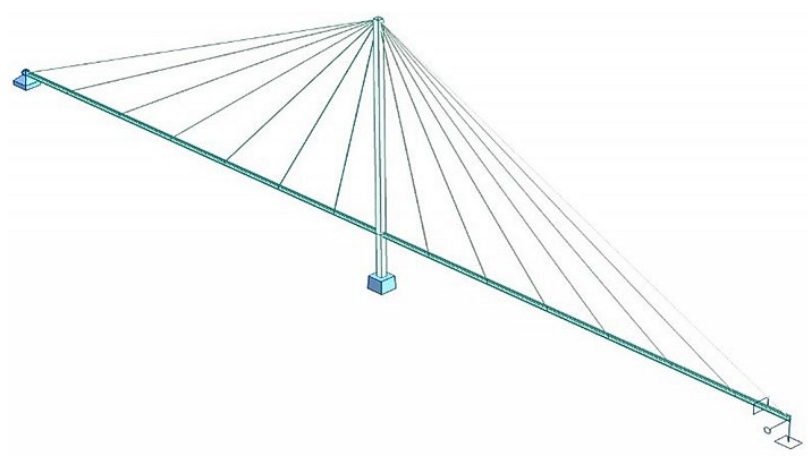

Figure 6. The structure scheme for the conventional cable-stayed bridge used for comparison with the new structure closer to the pylon, while they go downward in moving away from the pylon. This is due to the fact that the cables which are farther away from the pylon because of their smaller angle with the stiffening girder have a lower supporting effect. The highest value in the stiffening girder reaches $116.03 \mathrm{kNm}$, while the lowest in this case is only $7.59 \mathrm{kNm}$.

\section{The analysis of axial forces}

In the case of the symmetric load the maximum axial force is applied to the pylon (Figure 9). In the stiffening girder itself the axial compressive forces are distributed stepwise. In such a case the highest axial forces appear in the points where the stiffening girder is compressed from both sides. Such distribution of the cable-stayed bridge axial forces in the stiffening girder is rather unusual and varies unevenly throughout the entire length of the stiffening girder. The maximum axial force value in the stiffening girder reaches $1707.67 \mathrm{kN}$. The axial forces in cables vary depending both on the weight of the structure acting on it, and on the stiffness of the cables, as well as on the prestress force in them. The maximum axial force in the cables reaches $1512.49 \mathrm{kN}$.

In the case of the asymmetric load the maximum axial force is also applied to the pylon (Figure 10). The axial compression forces in the stiffening girder are distributed similarly to the case of the symmetric load. The maximum axial force in the cables reaches $1488.31 \mathrm{kN}$.

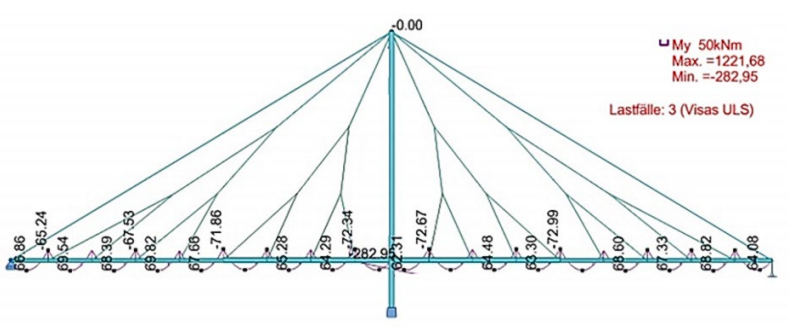

Figure 7. Diagram of the bending moments under symmetric load

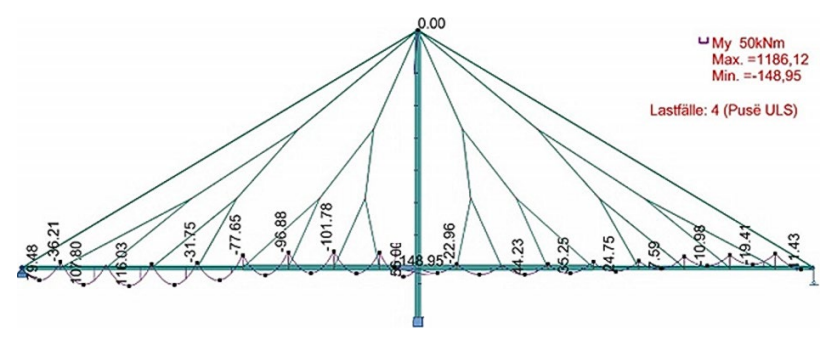

Figure 8. Diagram of the bending moments under asymmetric load

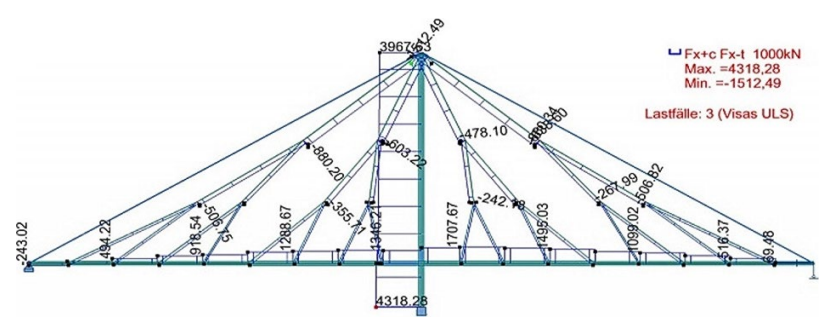

Figure 9. Diagram of the axial forces under symmetric load 


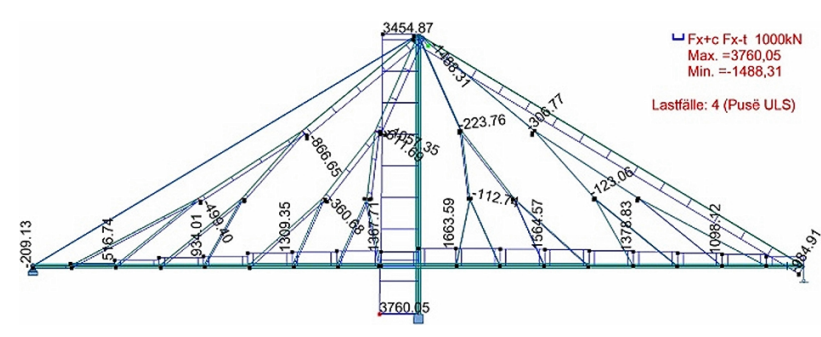

Figure 10. Diagram of the axial forces under asymmetric load

The analysis of the behaviour of the new structure of the cable-stayed bridge makes it evident that this structure is a promising and innovative one. In the case of asymmetric load, the bending moments formed in the stiffening girder are only 1.5 times higher than in the case of the symmetric load. Such indicator can effectively reduce the cross-section of the structural elements, thus reducing the dead load and the price of the bridge elements. The axial forces during the symmetric load are $14 \%$ stronger than in the case of asymmetric load, however, in the general case their values are small.

The behaviour analysis reveals the main advantages and disadvantages of the new structure, shows the key aspects to be addressed in the design of such a bridge.

\section{The conclusions of the bridge behaviour comparative analysis}

The cable-stayed bridge with cables branching two times (Figure 5) is an innovative structure with the main purpose of reducing the steel costs. Effective results can be achieved for two main reasons:

- The smaller number of cables is achieved due to the cable branching, which allows the cables to have a denser distribution and to make them considerably shorter;

- A denser arrangement of cables on the stiffening girder minimizes the bending moments and stresses are controlled more effectively in the case of asymmetric load, thus allowing the use of slenderer elements for the production of the stiffening girder.

One of the main features of this innovative structure is the distribution of the axial forces in the stiffening girder (Figure 9). It is common knowledge that the axial forces of the cable-stayed bridges closer to the pylon are growing. This is due to the fact that the stiffening girder is compressed by the horizontal component of the cable axial force which is directed towards the mounting of that cable. In the case of fan and hybrid cable-stayed bridges this component decreases slightly towards the pylon as the angle between the cable and the stiffening girder increases, in the case of parallel cable-stayed bridges this component grows at a constant rate. The performance of the two-level branched cable-stayed bridges is quite different since the angle of each cable with the stiffening girder varies and may even be greater than $90^{\circ}$. In this case the maximum axial forces are on the sections of the stiffening girder which are enclosed by two cables that branch from the same cable. If the angle of the cable with respect to the stiffening girder exceeds $90^{\circ}$, the maximum axial force is reached not in the part closest to the pylon, but on the section of the stiffening girder between the two cables the components of the horizontal axial forces of which are directed towards each other.

Such uneven distribution of axial forces in the stiffening girder allows to achieve highly effective stress control results. If the pedestrian load of $5 \mathrm{kN} / \mathrm{m}^{2}$ of the stiffening girder of the bridge is evenly distributed across the entire length, efficiency as high as $30 \%$ can be achieved compared to the case of the standard fan cable-stayed bridge (Figure 11). Meanwhile, applying such a load to only one side of the bridge increases the efficiency of the branched cable-stayed bridge up to $50 \%$, estimations being made according to the stresses on the stiffening girder (Figure 11). Such cost-efficient results are achieved because the axial forces in the stiffening girder do not grow in an even manner gradually up to the maximum value, but are distributed differently across the entire length of the stiffening girder.

Contrary to the conventional cable-stayed bridges the branched bridge is extremely insensitive to asymmetric loads. In terms of the axial forces this indicator is $50 \%$ better than in the case of the standard cable-stayed bridge (Figure 12). While the maximum axial force of $3265.19 \mathrm{kN}$ is reached under the asymmetric load at the stiffening girder of the standard cable-stayed bridge, the maximum axial force as low as $1663.59 \mathrm{kN}$ is reached at the stiffening girder of a two-level branched cable-stayed bridge with similar parameters. Even better results can be seen in terms of the bending moments (Figure 12).
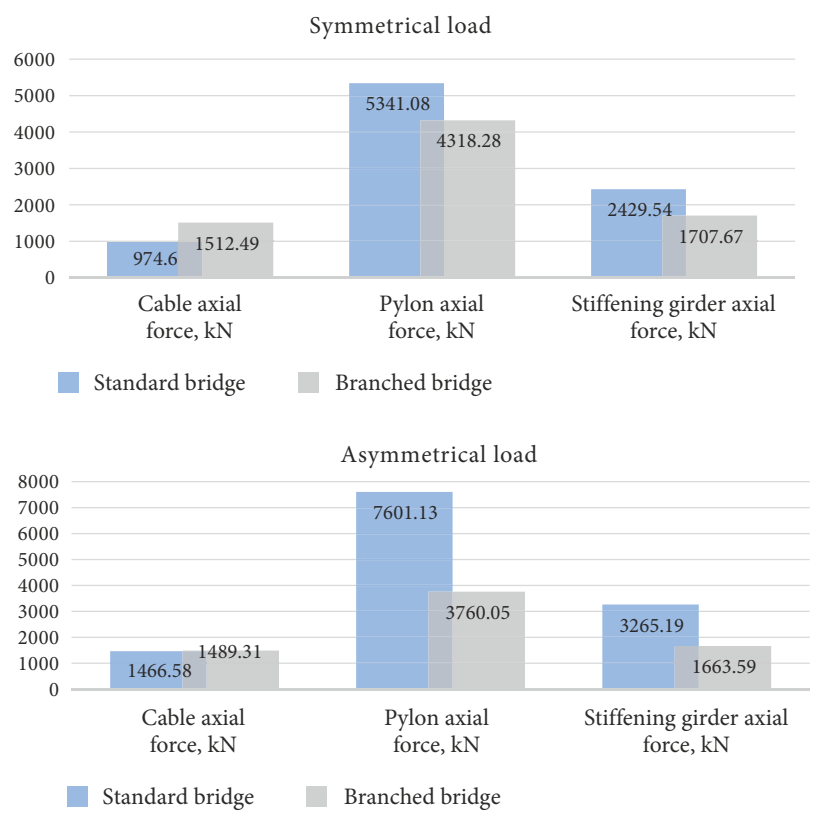

Figure 11. The results of the comparative analysis of the axial forces. The blue colour indicates the standard bridge data, the grey colour - the branched bridge data 


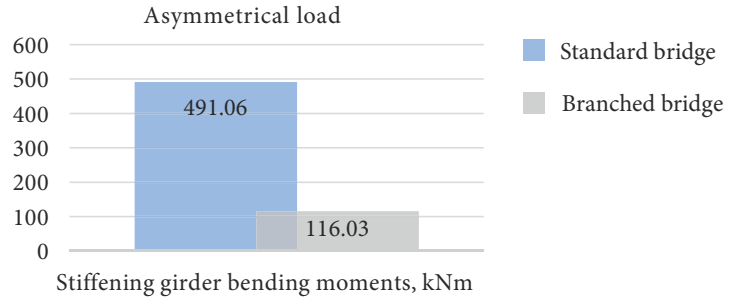

Figure 12. The results of the analysis of the bending moments in the stiffening girder. The blue colour indicates the standard bridge data, the grey colour - the branched bridge data

For instance, in the case of the asymmetric load on the stiffening girder the maximum bending moment reached at the branched cable-stayed bridge is even 4.2 times lower than that of the stiffening girder of the standard fan cablestayed bridge with analogous parameters, i.e. $116.03 \mathrm{kNm}$ and $491.06 \mathrm{kNm}$ respectively.

The interesting fact is that the difference between the maximum bending moment of the branched cable-stayed bridge stiffening girder with a symmetric and asymmetric load is $37 \%$, while in case of an equivalent span standard fan cable-stayed bridge it is as high as $74 \%$.

This particular indicator is the biggest advantage of the innovative two-level branched cable-stayed bridge design which makes it possible to minimize the cost of production of the stiffening girder. In any case both the axial forces and the bending moments in this new structure are smaller. This makes it possible to design slenderer elements of the bridge, to construct simpler connections, while in terms of aesthetics the design is even more lightweight and more valuable.

\section{Technical-economic efficiency}

One of the most significant indicators in the construction of bridges is their economic efficiency. The solutions for reducing the costs of construction work and materials are constantly under consideration. The branched cablestayed bridge helps save up to $34 \%$ of steel (Figure 13). Most importantly, the branched cable-stayed bridges require as much as $20 \%$ less steel than the standard cablestayed bridges. In the context of modern construction this indicator is very important while calculating the economic efficiency of bridge construction.

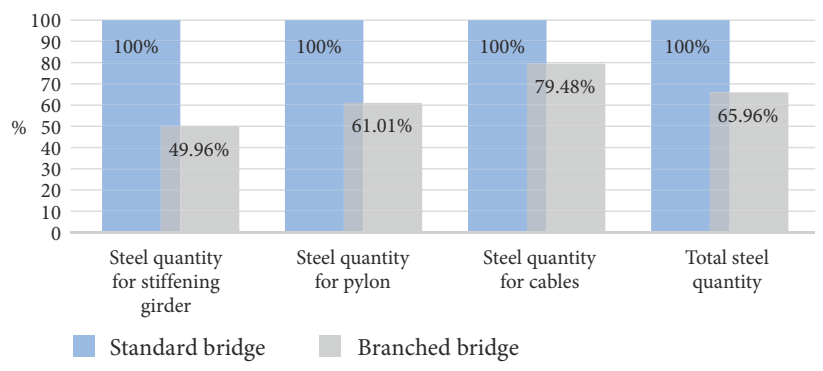

Figure 13. The results of the economic efficiency analysis. The blue colour indicates the standard bridge data, the grey colour - the branched bridge data
The highly effective control of stresses in the stiffening girder under asymmetric loads, the lesser amount of cables with their denser distribution and the uneven distribution of axial forces are the main reasons proving that a branched cable-stayed bridge is more cost-effective than the conventional cable-stayed bridges. Figure 11 shows that up to $50 \%$ less steel is used for the stiffening girder, $39 \%$ less steel for the pylons and 20\% less steel for the stay cables. Such results are achieved in the comparison of the $80 \mathrm{~m}$ span two-level branched cable-stayed bridge with a conventional fan bridge of the same span. In case of the increase of the span the cross-sections of all three elements grow. In other words, as the span grows, the economic efficiency of the two-level branched cable-stayed bridges is increasing even more.

\section{Conclusions}

With the rapid development of bridge construction technologies and the need for large spans, the search is on for new solutions that would deal not only with the structural but also the cost-effective implementation. One of the new and extremely promising systems is the branched cable-stayed bridges. The analysis of the deformed state behaviour of these bridges leads to the conclusion that this system can be one of the main cable-stayed bridge systems in pursuit of increasing the bridge spans up to record lengths.

The branched cable-stayed bridge structure allows to manage the asymmetric loads effectively which is an important indicator for reducing the cross-sections of the bridge elements. Such structure requires a lesser amount of cables. Designing such a structure is a complicated process, however, the development of a proper calculation methodology and practical recommendations can make this cable-stayed bridge structure one of the most promising (Stragys, 2018).

The study of the behaviour of the two-level branched cable-stayed bridge led to several main conclusions:

- The stiffening girder enclosed by two cables branching from a single point undergoes greater compression. For this reason, the axial forces in the stiffening girder of the cable-stayed bridges with cable branching vary unevenly;

- In order to achieve rational bending moments in the stiffening girder particular attention must be paid not only to the cable prestress, but also to many other parameters: the cable cross-section area, the connection coordinates, the determination of balance of the axial forces;

- The stiffening girder deflections of such cable-stayed bridges are strongly dependent on the balance of the axial forces in the cable branching. In case of imbalance of forces in such connection, large cable displacements occur which result in large displacements of the stiffening girder. A very important task is to control the branched structure displacements 
properly, as they can have a significant effect on the serviceability limit state;

- The most effective performance of the structure with cables branching from a single point takes place when the cable of the upper level is of larger crosssection than the cables branching from it;

- The reduction in the height between the cable connection and the stiffening girder " $h$ " produces intensive growth of the axial forces of that particular part of the stiffening girder, as the element is more compressed, i.e. the horizontal components of the axial forces of the cables are greater. A similar effect happens in the opposite case: when the height $h$ increases, the axial forces in the stiffening girder decrease;

- If the angle between the cable and the stiffening girder is greater than $90^{\circ}$, it leads to stretching in the latter. The reason for this is the following: the horizontal component of the cable axial force becomes directed towards the opposite side;

- For the latter two reasons the axial forces in the stiffening girder are distributed unevenly in case of such cable configuration. The compressive force of the elements enclosed by two cables branching from a single point is greater than that of the intermediate elements;

- The most cost-effective option is the one that uses more cables with smaller cross-section compared with the one using larger cross-section cables;

- With regard to stresses the most effective option is the one in which the difference between the maximum and minimum stresses in the stiffening girder is the smallest.

\section{References}

Dischinger, F. (1949). Hängebrücken fur Schwerste Verkehrslasten. Der Bauingenieur, 24, 65-75; 107-113.

Ernst, H. J. (1965). Der E-Modul von Seilen unter Brucksichtigung des Durchhangers. Der Bauingenieur, 40(2), 52-55.

Freire, A. M. S., Negrao, J. H. O., \& Lopes, A. V. (2006). Geometrical nonlinearities on the static analysis of highly flexible steel cable-stayed bridges. Computers and Structures, 84, 2128-2140. https://doi.org/10.1016/j.compstruc.2006.08.047

Ghali, A., \& Neville, A. M. (1978). Structural analysis: a unified classical and matrix approach. London: Chapman \& Hall.

Hagen, C., \& Staroseek, U. (2002). Zur Vorbemessung von Schrägseilbrücken. Hamburg.

Hajdin, N., Michaltsos, G. T., \& Konstantakopoulos, T. G. (1998). About the equivalent modulus of elasticity of cables of cablestayed bridges. The Scientific Journal FACTA UNIVERSITATIS (series Architecture and Civil Engineering), 1(5), 569-575.

Lietuvos Standartizacijos departamentas. (2006). Eurokodas 1. Poveikiai konstrukcijoms. 2 dalis. Tiltu eismo apkrovos (LST EN 1991-2:2006). Retrieved from https://www.lsd.lt/index. php?-393095731

Monaco, P. (1997). The tangent and secant modulus of cable stays with tension cables. Paper presented at the International Conference: New Technologies in Structural Engineering, 3-5 July, Lisbon, Portugal.
Nazmy, A. S., \& Abdel-Ghaffar, A. M. (1990). Three-dimensional nonlinear static analysis of cable-stayed bridges. Computers and Structures, 34(2), 257-271. https://doi.org/10.1016/0045-7949(90)90369-D

Podolny, W. (2011). Cable-suspended bridges. Structural steel designer's handbook. New-York City.

Stragys, M. (2018). Inovatyvaus šakotinio plieninio vantinio pėsčiųjų tilto lyginamoji analizè. Mokslas - Lietuvos ateitis / Science - Future of Lithuania, 10, 1-7. https://doi.org/10.3846/mla.2018.6260

Thai, H.-T., \& Kim, S.-E. (2012). Second-order inelastic analysis of cable-stayed bridges. Finite Elements in Analysis and Design, 53, 48-55. https://doi.org/10.1016/j.finel.2011.07.002

Vega-Posada, C., Areiza-Hurtado, M., \& Aristizabal-Ochoa, J. D. (2011). Large-deflection and post-buckling behavior of slender beam-columns with non-linear end-restraints. International Journal of Non-Linear Mechanics, 46, 79-95. https://doi.org/10.1016/j.ijnonlinmec.2010.07.006

Wang, P.-H., Lin, H.-T., \& Tang, T.-Y. (2002). Study on nonlinear analysis of a highly redundant cable-stayed bridge. Computers and Structures, 80, 165-182. https://doi.org/10.1016/S0045-7949(01)00166-3 